\title{
Isolation and characterisation of a novel trophoblast side-population from first trimester placentae
}

\author{
J L James ${ }^{1}$, D G Hurley ${ }^{2}$, T K J B Gamage ${ }^{1}$, T Zhang ${ }^{1}$, R Vather $^{3}$, P Pantham ${ }^{1}$, P Murthi ${ }^{4,5}$ \\ and L W Chamley ${ }^{1}$
}

${ }^{1}$ Department of Obstetrics and Gynaecology, FMHS, University of Auckland, 85 Park Road, Grafton, Auckland 1023, New Zealand, ${ }^{2}$ Systems Biology Laboratory, Melbourne School of Engineering, University of Melbourne, Parkville, Melbourne, Victoria 3010, Australia, ${ }^{3}$ Auckland District Health Board, Grafton, Auckland 1023, New Zealand, ${ }^{4}$ Department of Perinatal Medicine, Pregnancy Research Centre, and University of Melbourne, Melbourne, Victoria, Australia and ${ }^{5}$ Department of Obstetrics and Gynaecology, The Royal Women's Hospital, 20 Flemington Road, Parkville, Melbourne, Victoria, Australia

Correspondence should be addressed to J L James; Email: j.james@auckland.ac.nz

\begin{abstract}
The placenta is responsible for all nutrient and gas exchange between mother and baby during pregnancy. The differentiation of specialised placental epithelial cells called trophoblasts is essential for placental function, but we understand little about how these populations arise. Mouse trophoblast stem cells have allowed us to understand many of the factors that regulate murine trophoblast lineage development, but the human placenta is anatomically very different from the mouse, and it is imperative to isolate a human trophoblast stem cell to understand human placental development. Here we have developed a novel methodology to isolate a Hoechst side-population of trophoblasts from early gestation placentae and compared their transcriptome to differentiated trophoblast populations (cytotrophoblasts and extravillous trophoblasts) using microarray technology. Side-population trophoblasts clustered as a transcriptomically distinct population but were more closely related to cytotrophoblasts than extravillous trophoblasts. Side-population trophoblasts up-regulated a number of genes characteristic of trophectoderm and murine trophoblast stem cells in comparison to cytotrophoblasts or extravillous trophoblasts and could be distinguished from both of these more mature populations by a unique set of 22 up-regulated genes, which were enriched for morphogenesis and organ development and the regulation of growth functions. Cells expressing two of these genes (LAMA2 and COL6A3) were distributed throughout the cytotrophoblast layer at the trophoblast/ mesenchymal interface. Comparisons to previously published trophoblast progenitor populations suggest that the side-population trophoblasts isolated in this work are a novel human trophoblast population. Future work will determine whether these cells exhibit functional progenitor/stem cell attributes.

Reproduction (2015) 150 449-462
\end{abstract}

\section{Introduction}

The placenta is a fetal organ that forms the interface between the mother and baby. Trophoblasts, specialised epithelial cells only found in the placenta, play a key role in nutrient and gas exchange between mother and baby, and thus the regulation of trophoblast differentiation during placental organogenesis is crucial for fetal growth and health in utero.

In human embryos, the first differentiation step is the separation of the inner cell mass, which forms the embryo, and the trophectoderm from which all trophoblast lineages in the placenta arise. By 5 weeks of gestation, the villous placenta is characterised by a core of mesenchymal tissue containing fetal blood vessels, surrounded by a bi-layer of trophoblast comprising an inner layer of mononuclear villous cytotrophoblast, overlain by a multinucleated syncytiotrophoblast layer that covers the entire placenta and is in direct contact with the maternal blood. The syncytiotrophoblast is responsible for the exchange of nutrients and gasses between the maternal and fetal circulations and is also the major barrier separating the immunologically disparate maternal and fetal organisms. A third trophoblast population, extravillous trophoblasts, grow out from the tips of placental villi and invade the decidua, where they play a crucial role in adapting the uterine blood supply to support pregnancy.

Villous cytotrophoblasts were traditionally thought of as 'stem-like cells' with the ability to generate both extravillous trophoblasts and the syncytiotrophoblast. However, when cultured, isolated villous cytotrophoblasts (even from early gestation placentae) differentiate to form the multinucleated syncytiotrophoblast 
(Dodeur et al. 1990). Furthermore, work by ourselves and others has suggested that rather than existing as one homogenous bipotent population, cytotrophoblast subpopulations are primed to differentiate into either syncytiotrophoblast or extravillous trophoblast (Aboagye-Mathiesen et al. 1996, James et al. 2005, 2007, Telugu et al. 2013). Indeed, many epithelial stem cell populations have the ability to generate committed progenitors, referred to as transit amplifying cells, which are able to expand the progenitor pool in tissues with rapid growth or high turnover (Blanpain et al. 2007). In the placenta, it is likely that villous cytotrophoblasts represent this transit amplifying population and that a separate population of true trophoblast stem cells from which villous cytotrophoblasts arise also reside in placental villi.

At present we have a poor understanding of early cell lineage differentiation in the human placenta due to its relatively unique anatomy within the animal kingdom and the ethical issues involved in studying very early human placentae. The isolation of mouse trophoblast stem cells from the outer trophectoderm layer of murine blastocysts has allowed mouse trophoblast lineage differentiation to be almost completely mapped from blastocyst to functional placenta (Tanaka et al. 1998, Senner \& Hemberger 2010). However, no suitable model exists to test whether findings in the mouse are relevant to human placentae. Therefore, it is imperative to develop a human trophoblast stem cell model to understand how the human trophoblast lineages develop. Therefore, the objective of this work was to isolate a Hoechst sidepopulation of trophoblasts from first trimester human placentae and undertake the molecular characterisation of this population to evaluate its potential as a human trophoblast stem cell population.

\section{Methods}

First trimester placental tissue was obtained with written informed consent from Auckland Medical Aid Centre (AMAC), Auckland. This was approved by the Northern Regional X Ethics Committee, Auckland, New Zealand (NTX/06/04/035).

\section{Isolation of a Hoechst side-population from first trimester villi}

First trimester villous tissue (5.6-12.0 weeks gestation) was washed in PBS ( $\mathrm{pH} 7.4$ ) to remove all maternal blood. Villi were dissected from the membranes, transferred to $25 \mathrm{ml}$ tubes (LabServ, Auckland, New Zealand) and incubated with $10 \mathrm{ml}$ $0.25 \%$ trypsin (Gibco, Auckland, New Zealand) containing $200 \mu \mathrm{g} / \mathrm{ml}$ DNAse I (Sigma) in PBS per gram of tissue in a $37^{\circ} \mathrm{C}$ waterbath for $10 \mathrm{~min}$ (first trypsin digest). Villi were then gently mixed, $10 \mathrm{ml}$ PBS was added and villi were allowed to settle to the bottom of the tube. Supernatant was removed and villi were washed eight times with $20 \mathrm{ml}$ PBS to remove the extravillous trophoblasts and much of the syncytiotrophoblast layer, which was discarded. Next, $10 \mathrm{ml}$ 0.25\% trypsin containing $200 \mu \mathrm{g} / \mathrm{ml}$ DNAse I in PBS per gram of tissue was added and villi were incubated on a rocker at $4{ }^{\circ} \mathrm{C}$ for $7 \mathrm{~min}$, then left stationary at $4{ }^{\circ} \mathrm{C}$ for $16 \mathrm{~h}$ (second trypsin digest). Villi were then washed ten times in PBS and washes were collected through $70 \mu \mathrm{m}$ cell strainers into $50 \mathrm{ml}$ tubes (Becton Dickinson, Auckland, New Zealand) containing $5 \mathrm{ml}$ fetal bovine serum (FBS). Tubes were centrifuged at $450 \mathrm{~g}$ for $8 \mathrm{~min}$, and supernatants were aspirated. Cell pellets were combined into $15 \mathrm{ml}$ DMEM/F12 (Life Technologies) containing $5 \%$ FBS and incubated in a $10 \mathrm{~cm}$ petri dish in a humidified $37{ }^{\circ} \mathrm{C}$ environment with $5 \% \mathrm{CO}_{2}$ for $10 \mathrm{~min}$ to deplete contaminating fibroblasts by plastic adhesion. The cell suspension was removed, and the dish gently washed twice with $5 \mathrm{ml} \mathrm{DMEM/F12} \mathrm{containing} \mathrm{5 \%} \mathrm{FBS.} \mathrm{The} \mathrm{total} \mathrm{cell} \mathrm{suspension}$ $(25 \mathrm{ml})$ was divided into two universal tubes containing 20 and $5 \mathrm{ml}$ each and centrifuged at $450 \mathrm{~g}$ for $8 \mathrm{~min}$. In some experiments, cells were then incubated with $4.5 \mu \mathrm{g} / \mathrm{ml}$ of AlexaFluor647-conjugated anti-human HLA-A,B,C antibody (Clone W6/32, \#311414, Biolegend, San Diego, CA, USA) in DMEM/F12 containing 5\% FBS for 30 min prior to Hoechst staining. Supernatants were removed, pellets were resuspended, and $4 \mathrm{ml} \mathrm{DMEM/F12} \mathrm{containing} \mathrm{5 \%} \mathrm{FBS} \mathrm{and} 10 \mu \mathrm{g} / \mathrm{ml}$ Hoechst 33342 (Sigma-Aldrich) pre-warmed and pre-gassed in a $5 \% \mathrm{CO}_{2}$ environment was added to the larger pellet. For a negative control, $50 \mu \mathrm{M}$ verapamil hydrochloride (Sigma-Aldrich) was added to the tube of the smaller pellet. Tubes were incubated in a $37^{\circ} \mathrm{C}$ waterbath for $90 \mathrm{~min}$, then centrifuged at $450 \mathrm{~g}$ for $8 \mathrm{~min}$ at $4{ }^{\circ} \mathrm{C}$, supernatants were discarded and $2 \mathrm{ml}$ ice cold PBS containing $1 \mu \mathrm{g} / \mathrm{ml}$ propidium iodide (PI) (Invitrogen) was added for $5 \mathrm{~min}$ at $4{ }^{\circ} \mathrm{C}$. Tubes were washed with $20 \mathrm{ml}$ ice cold PBS and then centrifuged at $450 \mathrm{~g}$ for $8 \mathrm{~min}$ at $4{ }^{\circ} \mathrm{C}$. This wash step was repeated twice, then $2-3 \mathrm{ml}$ ice-cold PBS was added to the main cell pellet and $0.5 \mathrm{ml}$ ice-cold PBS was added to the verapamil hydrochloride control tube, and cell suspensions were transferred to sterile FACS tubes (Becton Dickinson) on ice. Cells were sorted on a Becton Dickinson Aria II SORP with the sample maintained at $4{ }^{\circ} \mathrm{C}$. A $100 \mu \mathrm{m}$ nozzle with 20 psi sheath pressure and sterile PBS as the sheath fluid was found to improve survival of the sorted cells. Some samples were sorted with an $85 \mu \mathrm{m}$ nozzle and 45 psi sheath pressure. Dead cells were excluded based on PI staining (552 nm excitation with a Coherent Sapphire laser at $70 \mathrm{~mW}$ and emission detection with 600 LPand $610 / 20$ BP filters). Doublets were excluded by gates on side scatter area vs height and forward scatter area vs height dot plots, and the single live cells were displayed on a Hoechst Red (635 LP and 670/50 BP filters) vs Hoechst Blue (450/50 BP) dot plot with linear scales. Hoechst 33342 cells were excited with a Coherent Genesis $355 \mathrm{~nm} 20 \mathrm{~mW}$ laser. The gate for side-population cells was determined by comparing the sample with the verapamil hydrochloride-treated control. Cells were sorted into tubes or plates with the standard purity precision mode (32/32/0) at a rate that maintained $90 \%$ efficiency or better, usually around 30005000 events/s.

\section{Characterisation of Hoechst side-population cells by immunohistochemistry}

Hoechst side-population cells were sorted into wells of a 96-well plate pre-coated with $50 \mu \mathrm{g} / \mathrm{ml}$ fibronectin (Sigma) 
containing $100 \mu \mathrm{l}$ of DMEM/F12 containing 5\% FBS, $1 \%$ penicillin-streptomycin and $1 \%$ glutamax (Sigma) and allowed to adhere for $2 \mathrm{~h}$ in a humidified $5 \% \mathrm{CO}_{2}$ environment at $37^{\circ} \mathrm{C}$. Media were removed and cells were fixed with $100 \mu \mathrm{l}$ of methanol for $10 \mathrm{~min}$. Cells were washed twice with PBS and blocked with the addition of $10 \%$ normal goat serum (NGS) in PBS containing $0.05 \%$ Tween (PBS-Tween) for $10 \mathrm{~min}$. Next, $100 \mu \mathrm{l}$ of primary antibody $(3.1 \mu \mathrm{g} / \mathrm{ml}$ vimentin (M072529, Dako, Glostrup, Denmark), HLA-G $(5 \mu \mathrm{g} / \mathrm{ml}$, AB7758, Abcam, Cambridge, UK) or W6/32 (ATCC clone HB-95, produced in this laboratory) or irrelevant IgG1 control antibody (Life Technologies) diluted in $10 \%$ NGS in PBS-Tween was added for $1 \mathrm{~h}$ at room temperature. Wells were washed twice in PBS-Tween, and a biotinylated anti-mouse IgG antibody (Jackson Immunoresearch, West Grove, PA, USA) diluted in $10 \%$ NGS in PBS-Tween was added for $1 \mathrm{~h}$ at room temperature. Wells were washed twice with PBS-Tween, and $100 \mu \mathrm{l}$ of streptavidin-488 (Invitrogen) diluted in PBS-Tween was added to the wells for $1 \mathrm{~h}$ at room temperature. Wells were washed two more times, and $2 \mu \mathrm{g} / \mathrm{ml}$ anti-cytokeratin 7 antibody conjugated to eFluor615 (EBI-42-9005-82, eBioscience, San Diego, CA, USA) was added for $1 \mathrm{~h}$ at room temperature in the dark. In other experiments, antibodies raised against IL1R2 $(1.25 \mu \mathrm{g} / \mathrm{ml}$, MAB263, Pharmaco, Auckland, New Zealand) were added first, followed by a biotinylated mouse anti-human IgG antibody and streptavidin-PE (Invitrogen), then cells or slides were incubated with antibodies raised against IL7R (CD127) directly conjugated to FITC (1:20, 351312, Biolegend, San Diego, CA, USA). Cells were counterstained with $10 \mu \mathrm{g} / \mathrm{ml}$ Hoechst 33342 diluted in PBS for $5 \mathrm{~min}$, washed twice with PBS and visualised on a Nikon Eclipse Ti inverted microscope (Nikon, Japan). When staining was quantified, five images (centre top, centre left, centre right, centre bottom and centre of the well) were captured for each well and the percentage of stained cells was quantified relative to Hoechst stained nuclei by digital image analysis (Image J, Bethesda, MD, USA). All experiments were repeated on cells isolated from at least three placentae.

\section{Transcriptomic comparison of extravillous trophoblasts, cytotrophoblasts and side-population trophoblasts}

To analyse different populations of trophoblasts isolated from the same placentae, the Hoechst side-population protocol was modified to allow immunofluorescent labelling of extravillous trophoblasts and villous cytotrophoblasts. Cells from the first trypsin digest were collected through $70 \mu \mathrm{M}$ cell strainers into $50 \mathrm{ml}$ tubes containing $5 \mathrm{ml} \mathrm{FBS}$, then centrifuged at $450 \mathrm{~g}$ for $8 \mathrm{~min}$. The cell pellet was resuspended and $90 \%$ of the cells were incubated for $30 \mathrm{~min}$ at $37^{\circ} \mathrm{C}$ with $5 \mu \mathrm{g} / \mathrm{ml}$ of FITC-conjugated antibodies raised against HLA-G (AB7904, Abcam, Cambridge, UK) in DMEM/F12 containing 5\% FBS, while the remaining $10 \%$ was incubated with DMEM/F12 containing $5 \%$ FBS only (negative control). Cells were centrifuged at $450 \mathrm{~g}$ for $8 \mathrm{~min}$, stained with PI and washed with PBS as described above. FITC-positive cells were sorted using a Becton Dickinson Aria II SORP. Dead cells and doublets were excluded as described above. FITC detection was performed by $488 \mathrm{~nm}$ excitation with 505 LP and 530/30 BP emission filters.

Cells from the second overnight trypsin digest were collected as described and incubated for $30 \mathrm{~min}$ at $37^{\circ} \mathrm{C}$ with $10 \mu \mathrm{g} / \mathrm{ml}$ of FITC-conjugated antibodies raised against $\beta 4$ integrin (AB22486, Abcam) in DMEM/F12 containing 5\% FBS, then stained with Hoechst 33342 and $\mathrm{PI}$ as described above. Ten percent of the cells from the second trypsin digest was incubated with DMEM/F12 containing 5\% FBS only, then incubated with Hoechst 33342 and verapamil hydrochloride as a negative control. Dead cells, doublets and side-population cells were detected as described above. FITC was detected by $488 \mathrm{~nm}$ excitation and 505 LP and 530/30 BP emission filters.

All cells were sorted into $2 \mathrm{ml}$ RNAse free tubes containing $0.5 \mathrm{ml}$ RNALater (Life Technologies). RNA was extracted using the Invitrogen PureLink mini-kit (Life Technologies) according to the manufacturer's instructions. RNA quality and quantity was assessed using Experion RNA HighSens chips (Bio-Rad) according to the manufacturer's instructions. RNA was converted to cDNA and amplified using a NuGEN Ovation Pico WTA system $\mathrm{V} 2$ kit according to the manufacturer's instructions (NuGEN, San Carlos, CA, USA). Purified cDNA was biotin labelled and hybridised to Affymetrix PrimeView microarrays (Affymetrix, Santa Clara, CA, USA).

Microarray data were quality checked and found to be of good quality and free from obvious outliers. Data were Robust Multiarray Average (RMA) normalised following background correction and log transformation. The limma package in the statistical language $R$ was used to assess the evidence for differential abundance of all RNA transcripts between each of the three groups (extravillous trophoblasts, cytotrophoblasts and Hoechst side-population trophoblasts). A blocked analysis was performed to correct for within-patient variance. Benjamini-Hochberg false-discovery rate (FDR) control was used to adjust $P$ values for differential expression. A coefficient of 1.2 (corresponding to a 2.29-fold change) with corrected $P$ values $<0.05$ were used as a cut-off to identify genes that were significantly different between populations. These data have been deposited in the Gene Expression Omnibus (GEO) database with accession number GSE57834.

To obtain transcriptomic profiles of previously isolated trophoblast progenitor cells (TBPC) and human embryonic stem cells (hESC) (Genbacev et al. 2011), Affymetrix CEL files were obtained from the National Center for Biotechnology Information's (NCBI) GEO (reference GSE30127). These data were reanalysed using the process described above to obtain a directly comparable set of profiles between the two experiments; in addition, lists of differentially expressed transcripts from this analysis were checked against the analysis in the original publication and found to be in agreement.

\section{Homeobox gene arrays}

Human HOX gene, a TaqMan based cDNA array (Life Technologies) for gene profiling, was used to screen for HOX genes that showed differential expression in extravillous trophoblasts, cytotrophoblasts and Hoechst side-population cells. Briefly, cDNA was prepared and added to a Universal Mastermix (Life Technologies) and distributed in a cDNA array 
96-well plate at $\sim 3 \mathrm{ng} /$ well in a $20 \mu \mathrm{l}$ reaction. The array plate contained 92 gene-specific primer sets for homeobox genes with a panel of four housekeeping gene primers for normalisation. These housekeeping genes consisted of $18 \mathrm{~S}$ ribosomal RNA (18S), hypoxanthine phosphoribosyltansferase 1 (HPRT1), glyceraldehyde-3-phosphate dehydrogenase (GAPDH) and $\beta$-actin (ACTB). The PCR was performed in an ABI Prism 7500 Sequence Detector (Life Technologies) under the following cycling parameters: $95^{\circ} \mathrm{C}$ for $10 \mathrm{~min}$, followed by 40 cycles of denaturation at $95{ }^{\circ} \mathrm{C}$ for $15 \mathrm{~s}$ and primer extension at $60{ }^{\circ} \mathrm{C}$ for $1 \mathrm{~min}$. Data (Ct values) were analysed using the ABI Sequence Detector System software version 2.0, and the relative gene expression values, or fold changes, were analysed using the DataAssist Software v3.0 (Applied Biosystems) and normalised to the geometric mean Ct value of the five housekeeping genes. Candidate genes were prioritised based on the difference in fold-change gene mRNA expression in extravillous trophoblasts, cytotrophoblasts and side-population trophoblasts.

\section{Real-time PCR}

RNA derived from extravillous trophoblasts, villous cytotrophoblasts and side-population trophoblasts isolated from three placentae (7.4, 8.4 and 10 weeks of gestation) was converted into cDNA at equal concentrations using a Superscript III reverse transcriptase kit (Life Technologies) according to the manufacturer's instructions. cDNA was amplified using a custom pre-amp pool (Life Technologies) and the expression of genes of interest was determined using Custom Taqman Microfluidic Arrays (Life Technologies) according to the manufacturer's instructions. For LAMA2, TCN, COL6A1 and COL6A2, cDNA was not amplified and individual Taqman probes were used according to the manufacturer's instructions. Gene expression was normalised to the geometric mean of GAPDH and a further three housekeeping genes (GUSB, UBC, IPO8) specifically selected for their stability between extravillous trophoblasts, cytotrophoblasts and first trimester placental lysate samples using Taqman endogenous control gene array cards (data not shown). Statistical analysis of gene expression was done using Prism GraphPad software using a repeated measure ANOVA followed by a Bonferroni post-test to compare the differences between cell populations. $P$ values $<0.05$ were considered statistically significant.

\section{Immunohistochemical localisation of markers of side- population trophoblasts in first trimester placentae}

Genes that were specifically up-regulated in side-population trophoblasts were localised in sections from at least five first trimester placentae from 5.6 to 12.5 weeks of gestation. Paraffin-embedded sections were de-waxed in xylene and taken to water using an ethanol gradient. Antigen retrieval was undertaken in a $1 \mathrm{mM}$ EDTA buffer $(\mathrm{pH}$ 8.0) in a pressure cooker and slides were then equilibrated in PBS for $15 \mathrm{~min}$. For some antibodies, frozen sections fixed in ice-cold acetone for 10 min were used. Immunohistochemistry on all sections was performed as described previously (James et al. 2007) using a Zymed Histostain Plus Kit (Life Technologies), and staining was developed with AEC+ chromogen (Dako, Auckland,
New Zealand). Primary antibodies reactive with collagen $6 \alpha 3$ $(5 \mu \mathrm{g} / \mathrm{ml}$, OAAF02910, Aviva Systems Biology) or laminin $\alpha 2$ $(1 \mu \mathrm{g} / \mathrm{ml}, \mathrm{AB} 55409$, Abcam) were used on paraffin embedded sections, while primary antibodies reactive with collagen $3 \alpha 1$ (0.5 $\mu \mathrm{g} / \mathrm{ml}$, AM20612PU-N, Acris Bioscience, Herford, Germany) or VCAM-1 (4 $\mu \mathrm{g} / \mathrm{ml}$, \#555645, BD Biosciences, Auckland, New Zealand) were used on frozen sections. In each case serial sections were stained with antibodies reactive with cytokeratin 7 $(0.4 \mu \mathrm{g} / \mathrm{ml}, \mathrm{M} 7018101-2$, Dako). An irrelevant IgG1 control antibody (Life Technologies) was used as a negative control.

\section{Results \\ A trophoblast Hoechst side-population exists within first trimester placental villi}

Trophoblasts are the only epithelial cell type within the placenta, thereby cytokeratin 7 is frequently used to distinguish cells of the trophoblast lineage from mesenchymal cells of the villous core that are cytokeratin 7 negative but vimentin positive (Fig. 1G). We established a novel trypsin digestion protocol to obtain mononuclear cells from first trimester villi that were 95\% cytokeratin 7 positive and vimentin negative $( \pm 2.3$ S.E., $n=3$ placentae, Fig. 1A). When these cells were incubated with Hoechst 33342 and analysed by flow cytometry, a side-population characteristic of many adult stem cell populations was observed (Fig. 1B). An average of $1.44 \%( \pm 0.32$ S.E., $n=30)$ of the cells were found within the side-population gate, and this side-population was enriched for trophoblasts with $98.5 \%$ of the cells expressing cytokeratin 7 and failing to express vimentin ( \pm 0.18 S.E., $n=3$ placentae) (Fig. 1D). $\beta 4$ integrinpositive cytotrophoblasts were sorted from the main cell population outside the side-population gate (non-sidepopulation cells). Quantification of $\beta 4$ integrin expression in side-population and non-side-population cells by FACS demonstrated that $8.85 \%$ ( $\pm 6.7 \%$ ) of sidepopulation trophoblasts were $\beta 4$ integrin positive, whereas $87.03 \%( \pm 4.9 \%, n=4$ placentae $)$ of nonside-population cells were $\beta 4$ integrin positive. Thus, $\beta 4$ integrin expression is not a common feature of sidepopulation trophoblasts and may appear to be expressed as these cells begin to differentiate down the cytotrophoblast lineage to facilitate their adhesion to and migration along the basement membrane of the villus. Of sidepopulation cells, 99.5\% did not express HLA-G, a marker of extravillous trophoblasts, indicating that these trophoblasts originated from within the placental villi ( \pm 0.2 S.E., $n=4$ placentae) (Fig. 1E). Along with their lack of vimentin expression, no isolated sidepopulation cells expressed class I HLA as determined by lack of reactivity with the $W 6 / 32$ antibody that recognises a public determinant present in all class I HLA molecules ( $n=3$ placentae) (Fig. 1F), demonstrating that these side-population cells are not mesenchymal cells. The low levels of mesenchymal cell contamination in side-population cells were confirmed by FACS, where 

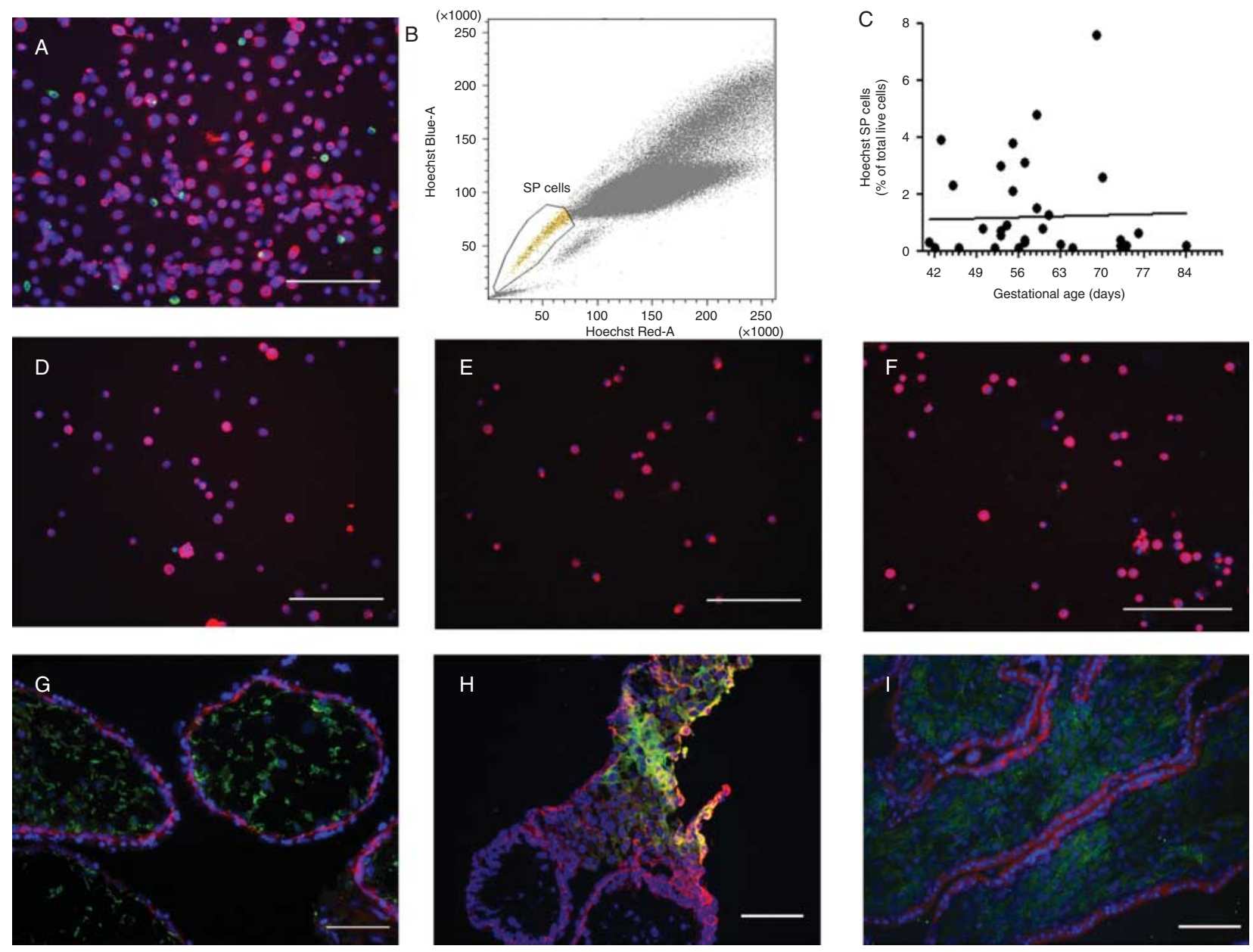

J $(\times 1000)$
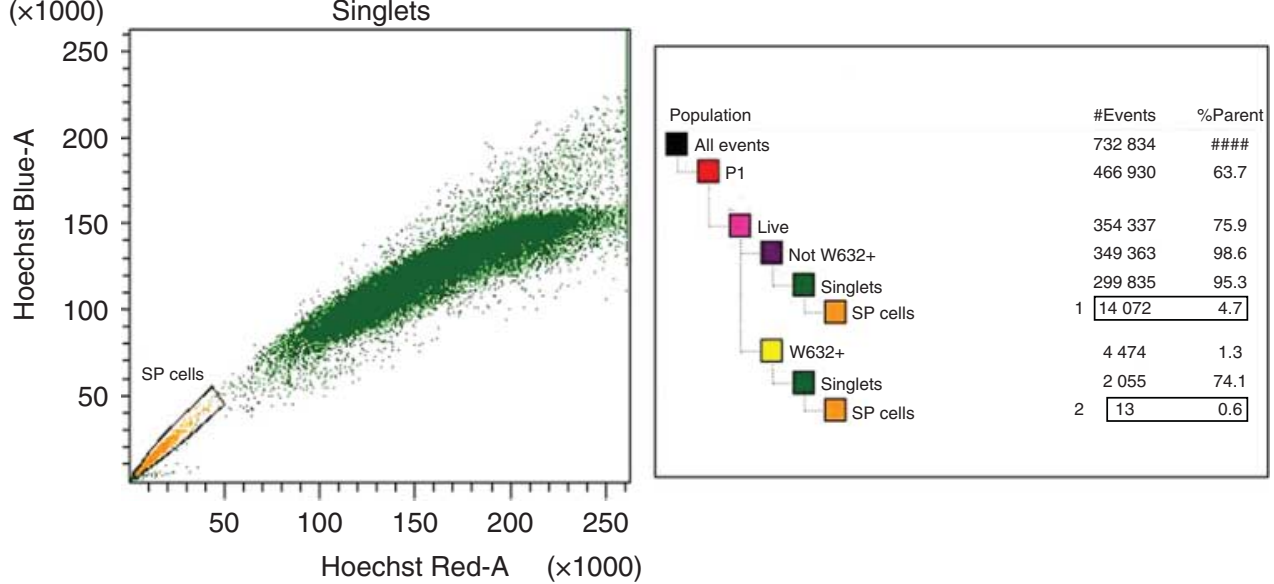

Figure 1 Characterisation of Hoechst side-population cells from first trimester placentae. When cells obtained from the digestion of first trimester placentae were labelled with Hoechst 33342 and analysed by flow cytometry, a clear Hoechst side-population (SP) can be observed (B). There was no significant trend in the proportion of side-population cells obtained in relation to gestational age across the first trimester (C). Mononuclear cells isolated from placentae prior to sorting by flow cytometry (A), Hoechst side-population cells isolated by flow cytometry (D, E and F), or sections of first trimester placentae $(\mathrm{G}, \mathrm{H}$ and $\mathrm{I})$ were labelled with antibodies reactive with vimentin (A, D and G), HLA-G (E and H) or MHC-1 (F and I) and detected using a FITC conjugated probe. All cells and sections were double labelled with antibodies reactive with cytokeratin 7 directly conjugated to eFluor615 and counterstained with Hoechst. This staining revealed that isolated Hoechst side-population cells were $98.5 \%$ trophoblast and did not express markers of extravillous trophoblasts (HLA-G) or mesenchymal stem cells (MHC-I). Scale bars represent $200 \mu \mathrm{m}$. Confirmation of a lack of MHC-1 expression in Hoechst side-population cells was confirmed by FACS (J). In the data shown here from a placenta of 8.4 weeks gestation (J), from a total of 14085 Hoechst side-population cells, 13 stained positively for MHC-I (0.09\%, Box 2), while 14072 (99.91\%, Box 1) did not stain with this marker. 
only $1.44 \%( \pm 0.71 \%)$ of the side-population cells expressed class I HLA (Fig. 1G). The proportion of cells that constitute the side-population did not change significantly with gestational age between 6 and 12 weeks of gestation (Fig. 1C, $n=30, P>0.05$ ).

\section{Global gene expression analysis suggests side-population trophoblasts are a separate population that express stem cell associated genes}

To characterise side-population trophoblasts more extensively, the transcriptome of matched sets of HLAG-positive extravillous trophoblasts, $\beta 4$ integrin-positive cytotrophoblasts and side-population trophoblasts isolated from the same placenta $(n=5$ placentae) were compared by Affymetrix PrimeView Array technology. Arrays were validated by comparing four individual genes of interest by real-time PCR (Fig. 2C, D, E and F).

Unsupervised hierarchical clustering of all transcripts using Ward's method revealed that four out five isolates of side-population trophoblasts formed a separate subpopulation that was more closely related to cytotrophoblasts than extravillous trophoblasts (Fig. 2A). Principal component analysis confirmed the relationships between these three populations (Fig. 2B).

To identify genes that were uniquely up- or downregulated in side-population trophoblasts in comparison to more differentiated trophoblast populations, we determined which genes were common to both i) sidepopulation trophoblasts relative to cytotrophoblasts and ii) side-population trophoblasts relative to extravillous trophoblasts. Twenty-two genes were significantly $(P<0.05)$ up-regulated $\geq$ twofold in side-population trophoblasts in relation to both cytotrophoblasts and extravillous trophoblasts (Table 1). However, no genes were significantly down-regulated $\geq$ twofold in sidepopulation trophoblasts in comparison to both cytotrophoblasts and extravillous trophoblasts. GATHER analysis (http://gather.genome.duke.edu/) shows that the 22 genes specifically up-regulated in side-population trophoblasts are enriched for morphogenesis and organ development and the regulation of growth functions.

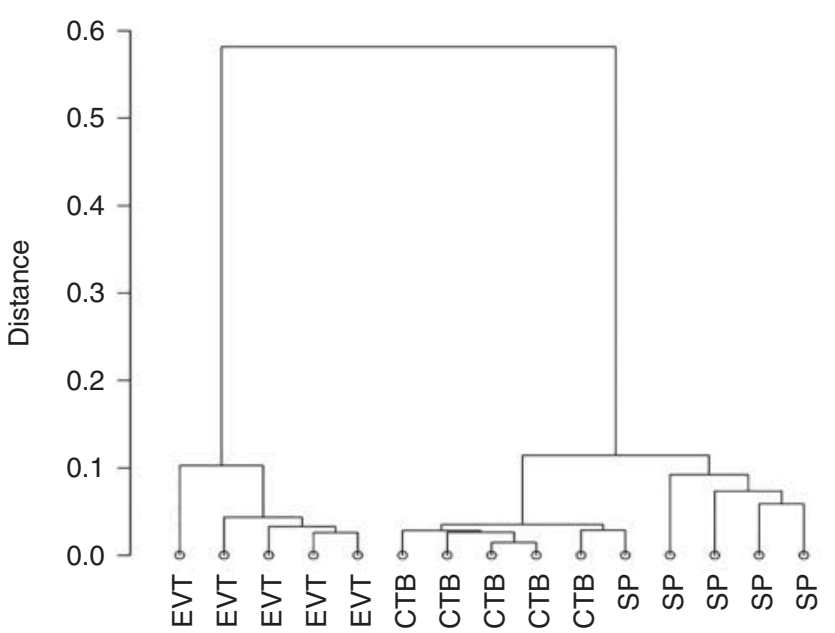

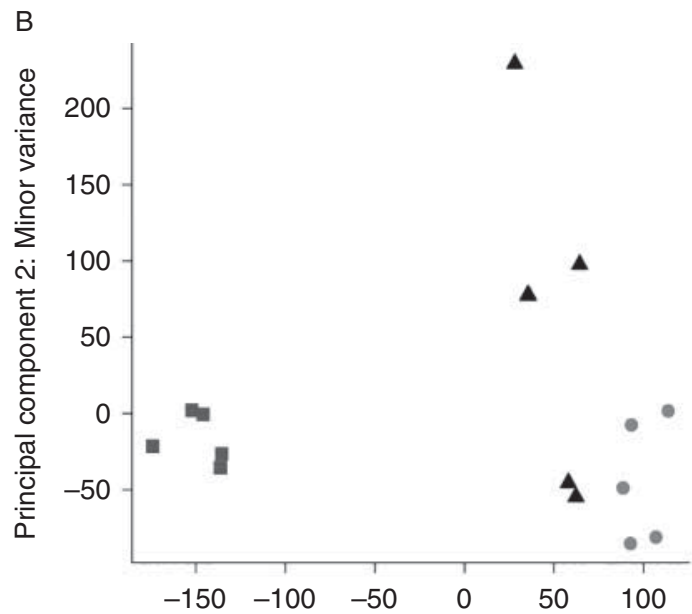

Principal component 1: Major variance
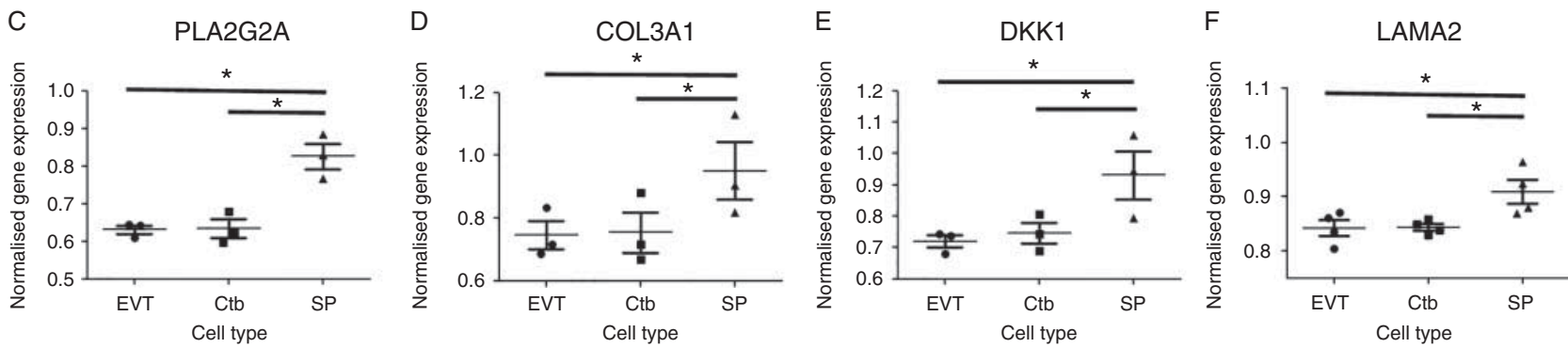

Figure 2 Transcriptomic analysis of Hoechst side-population trophoblasts (SP), cytotrophoblasts (Ctb) and extravillous trophoblasts (EVT) isolated from first trimester placentae. Cluster dendrogram analysis (A) and principal component analysis (B) demonstrate that Hoechst side-population trophoblasts (SP) form a transcriptomically distinct population within the placenta. The first two principal components are shown plotted against each other (B) with the side-population trophoblasts (triangles) separated from both the cytotrophoblasts (circles) and the extravillous trophoblasts (squares). The up-regulation of four of the 22 genes shown to be specifically up-regulated in SP cells relative to both Ctb and EVT by microarray was confirmed by real-time PCR. PLAG2A (C), COL3A1 (D), DKK1 (E) and LAMA2 (F) were significantly up-regulated in comparison to both Ctb and EVT, as was observed in the microarray data. ${ }^{*} P<0.05$. 
Table 1 Genes significantly $(P<0.05)$ up-regulated $\geq 2$-fold in Hoechst side-population trophoblasts in comparison to both cytotrophoblasts and extravillous trophoblasts as determined by Affymetrix PrimeView arrays. Genes are ranked in order of fold change from highest to lowest.

\begin{tabular}{|c|c|}
\hline Gene & Function/Biological significance \\
\hline PLA2G2A & $\begin{array}{l}\text { Phospholipase A2 group IIA: enzyme involved in lipid hydrolysis leading to the production of pro-inflammatory lipid mediators } \\
\text { (Aitken et al. 1996) }\end{array}$ \\
\hline IL6 & Interleukin-6: inflammatory cytokine \\
\hline IGFBP7 & $\begin{array}{l}\text { Insulin-like growth factor binding protein-7: prolongs the half-life and therefore actions of insulin-like growth factors (IGFs). } \\
\text { May play a role in regulating uterine receptivity (Liu et al. 2012) and inducing stem cell senescence (Severino et al. 2013) }\end{array}$ \\
\hline COL3A1 & Collagen $3 \alpha 1$ : extracellular matrix protein expressed during embryogenesis (Liu et al. 1997) \\
\hline SERPINE3 & $\begin{array}{l}\text { Serpin peptidase inhibitor, clade e (nexin, plasminogen activator inhibitor type 1), member } 3 \text { : protease inhibitor that regulates } \\
\text { cell migration }\end{array}$ \\
\hline CDR1 & Cerebellar degeneration-related protein 1: unknown function \\
\hline KLHL15 & $\begin{array}{l}\text { Kelch-like 15: Mediates ubiquitination and proteasomal degradation of target products. Implicated in the structural organisation } \\
\text { during embryogenesis. Increases the phosphorylation of Hand1 (Firulli et al. 2003), which when activated is able to inhibit } \\
\text { NANOG expression in the inner cell mass }\end{array}$ \\
\hline DNHD1 & Dynein heavy chain domain 1-like: microtubule based movement \\
\hline$D C N$ & $\begin{array}{l}\text { Decorin: Proteoglycan that interacts with collagen fibrils. Also a potent transforming growth factor } \beta \text { antagonist shown to regulate } \\
\text { progenitor cell differentiation (Fetting et al. 2014). Inhibits trophoblast migration and differentiation into an endovascular } \\
\text { phenotype (Lala et al. 2012) }\end{array}$ \\
\hline IGFBP5 & Insulin-like growth factor binding protein-5: prolongs the half-life and therefore actions of IGFs \\
\hline NR4A3 & $\begin{array}{l}\text { Nuclear receptor subfamily 4, group a, member 3: transcription factor that regulates proliferation, apoptosis and differentiation } \\
\text { (Mullican et al. 2007) }\end{array}$ \\
\hline$D K K 1$ & Dickkopf-related protein 1: Wnt signalling family member with a role in embryonic development \\
\hline THBS1 & Thrombospondin-1: adhesive glycoprotein that mediates cell-cell and cell-matrix interactions (Andraweera et al. 2011) \\
\hline MYLK & Myosin light chain kinase: plays a role in the regulation of epithelial cell survival (Connell \& Helfman 2006) \\
\hline VCAM1 & Vascular cell adhesion molecule 1: adhesion molecule \\
\hline EFNB2 & $\begin{array}{l}\text { Ephrin-B2: receptor protein-tyrosine kinase commonly expressed in stem cell niches and crucial for migration and adhesion } \\
\text { during epithelial tissue development (Genander \& Frisen 2010) }\end{array}$ \\
\hline COL6A3 & Collagen6a3: extracellular matrix protein \\
\hline FAM117A & Family with sequence similarity 117, member A: unknown function \\
\hline ATP1B1 & $\begin{array}{l}\text { Sodium/potassium-transporting ATPase subunit beta-1: integral membrane protein responsible for establishing and maintaining } \\
\text { the electrochemical gradients of } \mathrm{Na} \text { and } \mathrm{K} \text { ions across the plasma membrane. Involved in epithelial barrier formation } \\
\text { (Aschauer et al. 2013) }\end{array}$ \\
\hline$T N C$ & Tenascin-C: component of stem cell niches (Chiquet-Ehrismann et al. 2014) \\
\hline INTS6 & $\begin{array}{l}\text { Integrator complex subunit-6: Interacts with RNA polymerase to process small nuclear RNAs (snRNAs) that regulate transcription } \\
\text { factors and maintain telomeres. Regulates patterning during embryogenesis (Kapp et al. 2013) }\end{array}$ \\
\hline LAMA2 & $\begin{array}{l}\text { Laminin } \alpha 2 \text { : extracellular matrix protein that mediates the attachment, migration and organization of cells into tissues during } \\
\text { embryonic development }\end{array}$ \\
\hline
\end{tabular}

As extracellular matrix proteins featured strongly in the 22 genes specifically up-regulated in side-population trophoblasts, this finding was followed up further. As COL6A3 was found to be specifically up-regulated in side-population trophoblasts, real-time PCR was conducted to evaluate the expression of the other two collagen six chains. This revealed that COL6A2 was significantly up-regulated in side-population trophoblasts in comparison to both extravillous trophoblasts $(P<0.05)$ and cytotrophoblasts $(P<0.005, n=4)$, whereas COL6A1 showed a reduced expression in cytotrophoblasts in comparison to both extravillous trophoblasts $(P<0.05)$ or side-population trophoblasts $(P<0.005, n=4)$ (data not shown). Furthermore, real-time PCR confirmed the specific up-regulation of LAMA2 (Fig. 2) and TNC (data not shown) by sidepopulation trophoblasts.

When side-population trophoblasts were compared only to cytotrophoblasts, to which they are the most closely related, 297 genes were significantly (FDRadjusted $P<0.05)$ up-regulated $\geq$ twofold and 22 genes were significantly down-regulated $\geq$ twofold in sidepopulation trophoblasts. Pathway analysis using the GATHER tool revealed that these up-regulated genes were enriched for antigen processing and presentation, immune responses, metabolism, cell adhesion and transcription functions. When side-population trophoblasts were compared only to extravillous trophoblasts, 1557 genes were significantly up-regulated $\geq$ twofold and 1434 genes were significantly down-regulated $\geq$ twofold in side-population trophoblasts. GATHER pathway analysis revealed that these up-regulated genes were enriched for development, cell proliferation and cell cycle regulation and morphogenesis functions. A number of genes up-regulated in side-population trophoblasts have previously been identified as being important in trophectoderm lineage specification in both humans and mice (e.g., ELF5, TEAD4), while others have roles in maintaining other stem cell populations in an undifferentiated state (e.g., WNT5A, KLF4 and POU3F1) (Table 2). Supportive of the notion that side-population trophoblasts are committed to the trophoblast lineage, no significant differences in the inner cell mass markers POU5F1 (OCT4), SOX2 or NANOG were observed between side-population trophoblasts, villous cytotrophoblasts and extravillous trophoblasts. Side-population trophoblasts showed no significant difference in gene expression of the key mesenchymal stem cell markers 
Table 2 Genes of interest up-regulated in Hoechst side-population trophoblasts as determined by Affymetrix Primeview arrays.

\begin{tabular}{|c|c|c|c|}
\hline Gene & $\begin{array}{l}\text { Fold change in } \\
\text { expression in SP } \\
\text { relative to CTB }\end{array}$ & $\begin{array}{l}\text { Fold change in } \\
\text { expression in SP } \\
\text { relative to EVT }\end{array}$ & Biological significance \\
\hline$A B C G 2$ & $3.00^{*}$ & 1.39 & $\begin{array}{l}\text { Transporter protein characteristic of stem cell populations that is thought to be } \\
\text { largely responsible for the increased efflux of Hoechst } 33342 \text { (Zhou et al. 2001) }\end{array}$ \\
\hline TEAD2 & $7.33^{+}$ & 3.06 & Both expressed at significant levels in pre-implantation mouse embryos. TEAD2 \\
\hline TEAD4 & 1.17 & $5.12^{\neq}$ & $\begin{array}{l}\text { plays important roles in restricting cell differentiation (Tamm et al. 2011). TEAD4 } \\
\text { is critical to activate genes required for establishment of the trophectoderm } \\
\text { lineage (Yagi et al. 2007) }\end{array}$ \\
\hline HAND1 & 1.49 & $2.36^{*}$ & $\begin{array}{l}\text { Member of the basic helix-loop-helix family of transcription factors with high } \\
\text { sequence similarity. Closely related to HAND2, which binds to the promoter } \\
\text { region of NANOG and down-regulates the expression of this ICM-associated } \\
\text { gene (Hashimoto et al. 2009) }\end{array}$ \\
\hline ELF3 & 1.27 & $5.8^{\ddagger}$ & $\begin{array}{l}\text { Unknown function in human placenta. Part of a family of transcription factors that } \\
\text { regulate epithelial cell differentiation (Oliver et al. 2012) }\end{array}$ \\
\hline ELF5 & 1.22 & $26.23^{\ddagger}$ & $\begin{array}{l}\text { A critical gatekeeper gene of trophectoderm differentiation in the mouse, and } \\
\text { although expressed throughout the cytotrophoblast in humans, the interaction of } \\
\text { ELF5 with CDX2 is thought to be key for human trophoblast stem cell function } \\
\text { (Hemberger et al. 2010) }\end{array}$ \\
\hline POU3F1 (Oct-6) & 1.28 & $5.57^{+}$ & $\begin{array}{l}\text { Unknown function in human placenta. Expressed in embryonic stem cells and acts } \\
\text { as an intrinsic regulator of stem cell survival and self-renewal in mouse } \\
\text { spermatogonial stem cells (Suzuki et al. 1990) }\end{array}$ \\
\hline POU2F3 (Oct-11) & 1.09 & $2.29 *$ & $\begin{array}{l}\text { Unknown function in human placenta. Interacts synergistically with ELF3 } \\
\text { (Oliver et al. 2012) }\end{array}$ \\
\hline WNT5A & 1.28 & $4.18^{\ddagger}$ & $\begin{array}{l}\text { Canonical WNT5A signalling through Frizzled and LRP5/LRP6 receptors acts to } \\
\text { maintain stem cells in an undifferentiated state (Katoh 2007) }\end{array}$ \\
\hline FZD5 & 1.18 & $5.49^{\ddagger}$ & Frizzled receptor for WNT5A (Katoh 2007) \\
\hline WNT7B & 1.79 & $2.86^{*}$ & $\begin{array}{l}\text { Central to the early stages of mammalian placental development (Parr et al. 2001, } \\
\text { Cross et al. 2003) }\end{array}$ \\
\hline FZD10 & 1.27 & $4.96^{\dagger}$ & Frizzled receptor for WNT7B (Parr et al. 2001, Cross et al. 2003) \\
\hline LRP5 & 1.63 & $14.80^{\ddagger}$ & $\begin{array}{l}\text { Co-receptor required for both WNT5A and WNT7B to activate the canonical Wnt } \\
\text { pathway (MacDonald \& He 2012) }\end{array}$ \\
\hline BMP4 & 1.28 & $3.79^{+}$ & $\begin{array}{l}\text { Cytokine that is able to induce hESC to differentiate down the trophoblast lineage } \\
\text { and thus may regulate the first trophectoderm differentiation events in the } \\
\text { blastocyst (Golos et al. 2013) }\end{array}$ \\
\hline FGF2 & 1.56 & $4.02 *$ & $\begin{array}{l}\text { Suppresses hESC differentiation into differentiated trophoblast lineages (Das et al. } \\
\text { 2007, Sudheer et al. 2012) }\end{array}$ \\
\hline KLF4 & 1.3 & $2.21^{*}$ & $\begin{array}{l}\text { One of the four major pluripotency factors used to generate induced pluripotent } \\
\text { stem cells (Takahashi \& Yamanaka 2006) }\end{array}$ \\
\hline
\end{tabular}

Statistically significant values are labelled either $* P<0.05,{ }^{+} P<0.01$ or ${ }^{\ddagger} P<0.001$. SP, Hoechst side-population trophoblasts; CTB, cytotrophoblast; EVT, extravillous trophoblasts.

THY1 (CD90) or NT5E (CD73) in comparison to both cytotrophoblasts and extravillous trophoblasts, further confirming that side-population samples were not confounded by mesenchymal stem cell contamination (data not shown).

\section{Homeobox array analysis suggests side-population trophoblasts are a separate population of trophoblasts}

Homeobox genes encode transcription factors that switch on gene cascades within cells and thus play an important role in cell differentiation during embryogenesis as well as controlling proliferation and differentiation in a number of stem cell populations (Murthi et al. 2011). Due to their potential importance in regulating stem cell differentiation within the placenta the expression of homeobox genes in side-population trophoblasts, villous cytotrophoblasts and extravillous trophoblasts (from three placentae) was compared using a Human HOX gene cDNA array. Of the 92 homeobox genes analysed in the array, nine were up-regulated more than 1.5 -fold in side-population trophoblasts in comparison to both villous cytotrophoblast and extravillous trophoblast (Fig. 3A). Of particular interest three genes - CDX1, CDX2 and HOXD9 - were up-regulated more than fivefold (Fig. 3A). However, when CDX2 and HOXD9 were validated by real-time PCR in individual cell populations sorted from the same placenta $(n=3)$ only HOXD9 was shown to be significantly up-regulated in side-population cells in comparison to extravillous trophoblasts (Fig. 3B and C). No homeobox genes were down-regulated more than 1.5 -fold in side-population trophoblasts in comparison to both cytotrophoblasts and extravillous trophoblasts.

\section{Side-population trophoblasts differ from previously isolated trophoblast progenitor populations and embryonic stem cells}

It has previously been reported that a TBPC population was isolated from the chorion of first trimester placentae (Genbacev et al. 2011). To determine how similar our villus-derived side-population trophoblasts were to this 


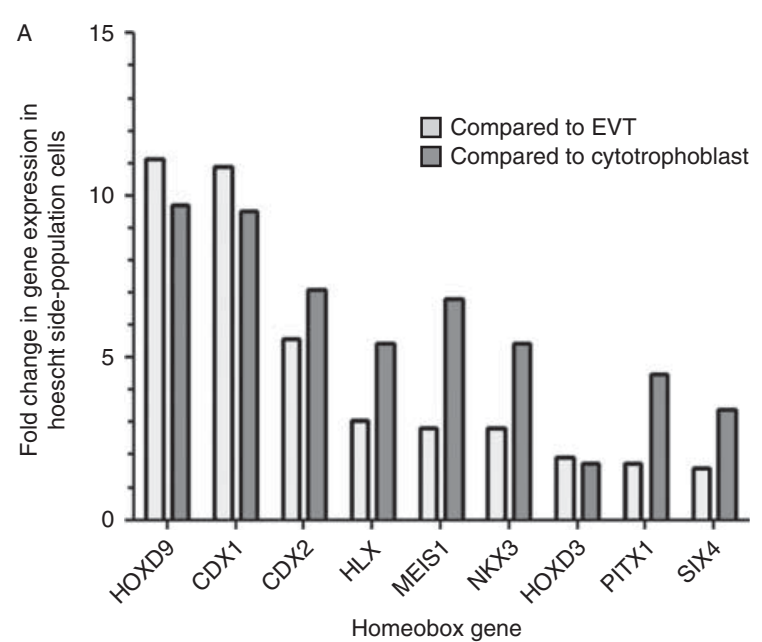

B

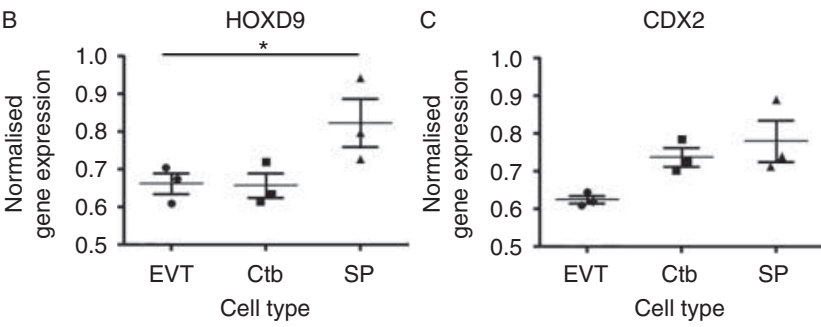

Figure 3 Homeobox gene expression in Hoechst side-population trophoblasts (SP), cytotrophoblasts $(\mathrm{Ctb})$ and extravillous trophoblasts (EVT) isolated from first trimester placentae. Histogram demonstrating significant up-regulation of nine homeobox genes more than 1.5-fold in Hoechst side-population trophoblasts (SP) relative to Ctb and EVT (A). Gene expression of HOXD9 (B) and CDX2 (C) was also determined by real-time PCR. ${ }^{*} P<0.05$.

previously published chorionic TBPC population, we reanalysed the data to compare genes that were significantly $(P<0.05)$ up- or down-regulated more than twofold in side-population trophoblasts relative to cytotrophoblasts with genes up- or down-regulated more than twofold in TBPC relative to cytotrophoblasts. This demonstrated that only two out of $297(0.75 \%)$ genes (COL3A1 and MYO1B) that were up-regulated more than twofold in side-population trophoblasts were also up-regulated in TBPC (Fig. 4A). No genes were commonly down-regulated between these two groups (Fig. 4B). This lack of similarity in gene expression suggests that our side-population trophoblasts are not the same cell population as the previously published TBPC.

To determine how similar our side-population trophoblasts were to hESCs, we reanalysed previously published microarray data of gene expression in hESC relative to cytotrophoblasts (Genbacev et al. 2011) to compare this to our microarray data of gene expression in side-population trophoblasts relative to cytotrophoblasts. This showed that 166 out of 297 (57\%) genes that were expressed at levels more than twofold greater in side-population trophoblasts relative to cytotrophoblasts were also expressed more than twofold greater in hESC relative to cytotrophoblasts (Fig. 4C). GATHER pathway analysis revealed that these genes were primarily enriched for antigen processing and presentation and immune response functions. In line with the ability of differentiated trophoblasts to evade the maternal immune system, this suggests that this difference may result from cytotrophoblasts down-regulating these genes as they differentiate from side-population trophoblasts or hESC. Four out of $22(18 \%)$ genes that were expressed at levels more than twofold less in side population trophoblasts relative to cytotrophoblasts were also expressed more than twofold less in hESC relative to cytotrophoblasts (C2orf43, CDC25C, FGFR2 and RDM1) (Fig. 4D). Because of the differing sizes of up- and down-regulated gene lists in the two datasets, we repeated this comparison using the top 200 up- and down-regulated genes only and found similar trends (data not shown). Taken together, these results indicate that side-population trophoblasts have some common features with hESC but are a distinct cell population.
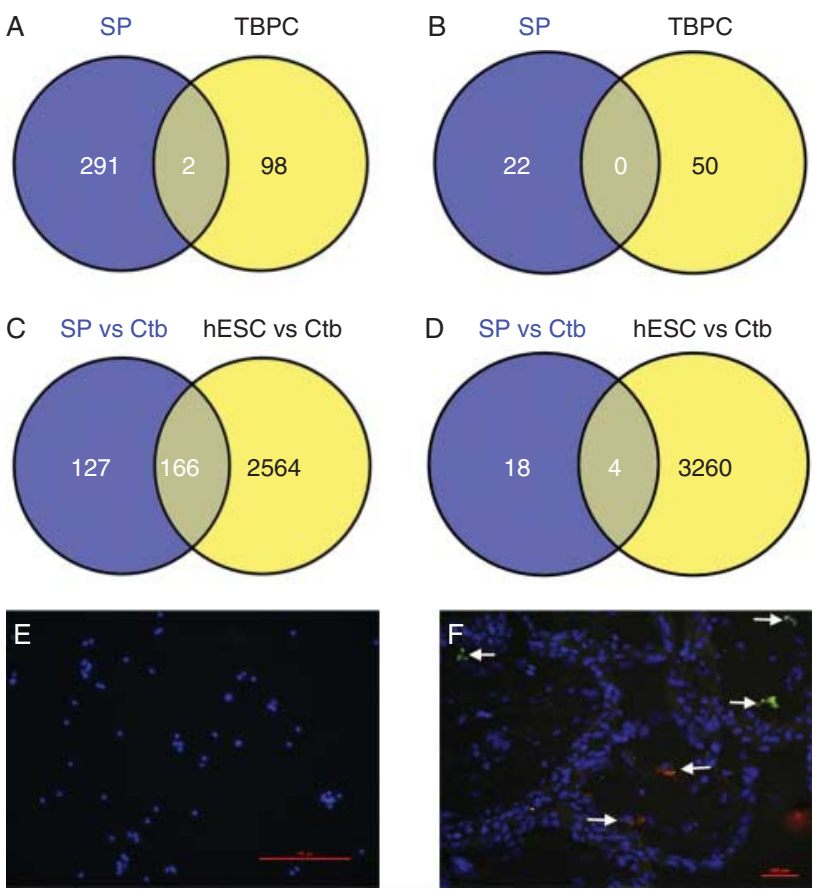

Figure 4 Comparison of side-population trophoblasts to other trophoblast progenitor populations. Venn diagrams demonstrating the overlap in genes up-regulated $\geq$ twofold $(A)$ or down-regulated $\geq$ twofold (B) in Hoechst side-population trophoblasts (SP) or trophoblast progenitor cells (TBPC) relative to cytotrophoblasts. Venn diagrams demonstrating the overlap in genes up-regulated $\geq$ twofold (C) or down-regulated $\geq$ twofold (D) in SP or human embryonic stem cells (hESC) relative to cytotrophoblasts. Immunofluorescent double labelling demonstrates that Hoescht side-population trophoblasts isolated from an 8.0-week placenta do not express IL7R (green) or IL1R2 (red) (E) and that these markers are restricted to the mesenchymal core of first trimester placental tissue (arrows) (F). Scale bars represent $100 \mu \mathrm{m}$. 
Takao et al. (2011) reported that a side-population could be isolated from the trophoblast cell line HTR8/ SVneo and from isolated villous cytotrophoblasts and that these side-population cells exclusively expressed interleukin-7 receptor (IL7R) and interleukin-1 receptor 2 (IL1R2). However, when our side-population trophoblasts were sorted onto Matrigel-coated wells and immunofluorescently labelled for IL7R or IL1R2, no expression of either of these markers was observed (Fig. 4E). Furthermore, expression of IL7R and IL1R2 in sections of first trimester placental tissue appeared to be restricted to the mesenchymal core of placental villi (Fig. 4F). Therefore, the differing methodology by which our side-population trophoblasts were obtained in this work has resulted in a side-population of trophoblasts that differs from those previously isolated by Takao et al.

\section{Localisation of markers of the side-population trophoblasts in first trimester placenta}

To localise side-population trophoblasts within placental villi, the expression of proteins encoding genes that were specifically up-regulated in side-population trophoblasts relative to cytotrophoblasts and extravillous trophoblasts was determined in first trimester placental sections by immunohistochemistry (Fig. 5). Serial sections were labelled with antibodies reactive with cytokeratin 7 to identify trophoblasts (Fig. 5E, F, G and H). Laminin $\alpha 2$
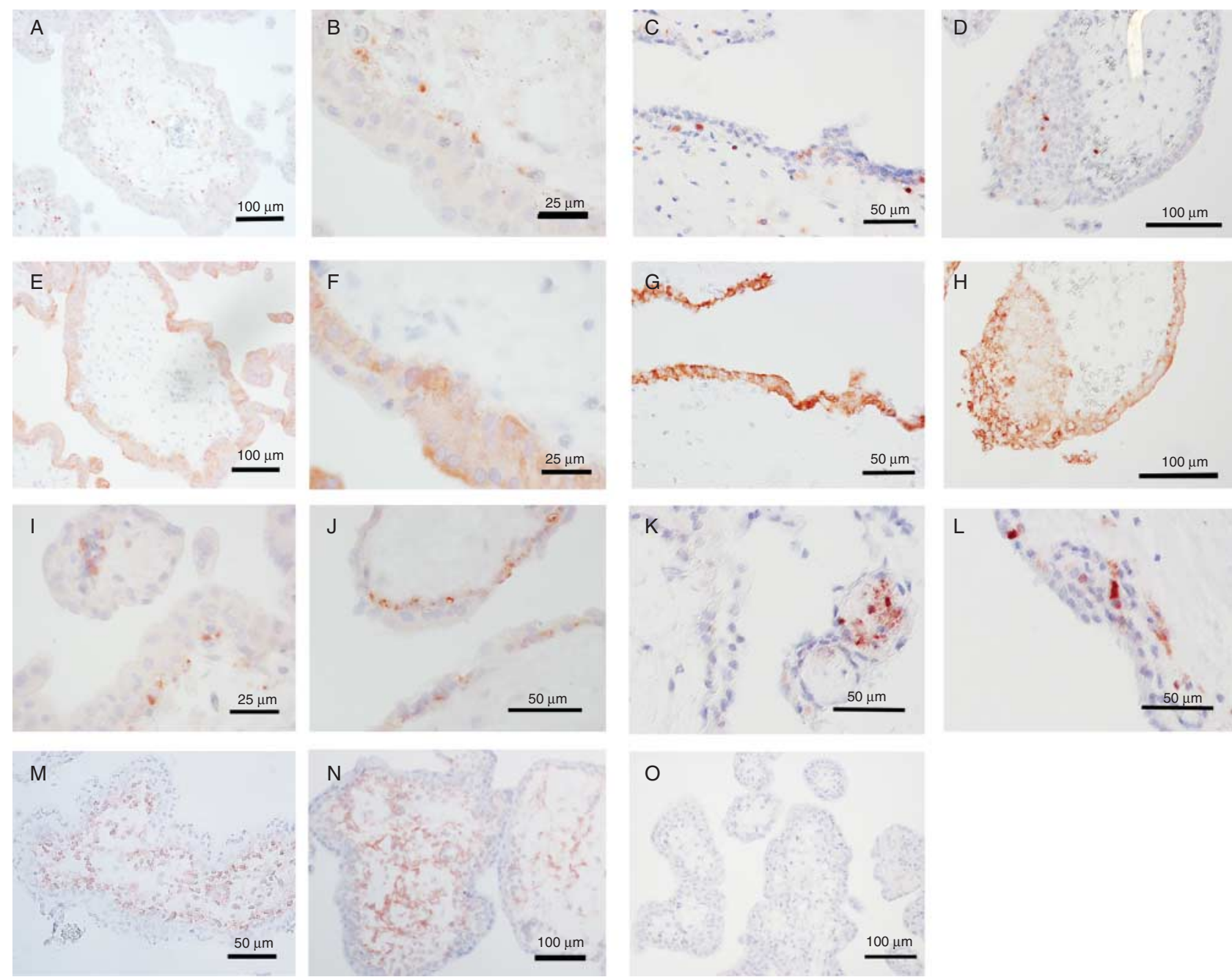

Figure 5 Protein expression of side-population trophoblast up-regulated genes in first trimester villous tissue. Photomicrographs demonstrating immunohistochemical staining of first trimester villous tissue with antibodies reactive with laminin $2 \alpha$ (A, B; 9.1 weeks of gestation) or collagen $6 \alpha 3$ (C, D; 10.0 weeks of gestation) and serial sections labelled with antibodies reactive with cytokeratin 7 (E, F, G and $\mathrm{H})$ demonstrates expression by isolated cells at the cytotrophoblast/mesenchyme border. Collagen $6 \alpha 3$ was also expressed in multilayered trophoblasts in villus tips producing EVT outgrowth (D). The same pattern of staining for laminin $2 \alpha(\mathrm{I}, 10.0$ weeks; J, 8.1 weeks) and collagen $6 \alpha 3$ (K, 5.6 weeks; $\mathrm{L}, 8.0$ weeks) was seen in tissues of different gestational ages within the first trimester. VCAM-1 (M, 11.3 weeks of gestation) and collagen $3 \alpha 1$ (N, 8 weeks of gestation) were expressed throughout the villus core. Negative controls were incubated with irrelevant IgG1 at equivalent antibody concentrations (O). All images are counterstained with haematoxylin. 
expression was observed at focal sites along the cytotrophoblast/mesenchymal boundary, as well as in occasional mesenchymal cells and blood vessel walls within the placental villi (Fig. $5 \mathrm{~A}$ and $\mathrm{B}, n=5$ ). Similarly, collagen $6 \alpha 3$ was expressed in sporadic cells within the villus, within both the mesenchyme and the cytotrophoblast layer (Fig. 5C, $n=5$ ). Sporadic cells also stained strongly for collagen $6 \alpha 3$ underlying extravillous trophoblast outgrowth, while more diffuse staining was observed in extravillous trophoblasts (Fig. 5D). At times, staining for both laminin $\alpha 2$ and collagen $6 \alpha 3$ could be observed in cells embedded in the stroma directly beneath the main cytotrophoblast layer, whereas at other times these cells appeared to form part of the cytotrophoblast monolayer directly beneath the syncytiotrophoblast. V-CAM-1 and collagen $3 \alpha 1$ were expressed throughout the mesenchymal core of the villi, as well as in cells likely to be trophoblasts directly adjacent to the syncytiotrophoblast (Fig. $5 \mathrm{I}$ and $\mathrm{J}, n=5$ ). Although we cannot be absolutely certain of the specificity of these markers for sidepopulation cells, taken together, these results suggest that side-population trophoblasts are sparsely distributed throughout the cytotrophoblast layer, including cells underlying the extravillous trophoblast columns, and are in direct contact with the mesenchymal core of the villi.

\section{Discussion}

Our understanding of human placental development is significantly hampered by the lack of accurate models with which to study these early processes. To overcome this, we used the Hoechst side-population technique of isolating progenitor and stem cell populations (Redvers et al. 2006, Samuel et al. 2009, Shaharuddin et al. 2014) to isolate a novel population of trophoblasts from first trimester placentae and characterised these side-population trophoblasts with respect to more differentiated trophoblast populations. This revealed that side-population trophoblasts are a transcriptomically distinct population within the placenta and express a number of genes characteristic of other pluripotent stem cell populations and murine trophoblast stem cells.

The Hoechst side-population technique has been used to identify adult stem cell populations in a range of organs including the heart, liver and kidney, as well as epithelial tissues with well-defined stem cell populations such as skin, colon and the corneal limbus (Redvers et al. 2006, Samuel et al. 2009, Shaharuddin et al. 2014). In this work, we used this technique to isolate a population of trophoblasts from first trimester placental villi that are $98.5 \%$ pure. Side-population cells constituted $1.44 \%$ of the total live trophoblasts analysed, a proportion only slightly higher than the number of side-population cells previously derived from the colon $(0.7 \%)$, an epithelial tissue known for high cellular turnover in a manner similar to the placenta (Samuel et al. 2009). Therefore, the proportion of side-population trophoblasts obtained in this work is in line with expectations for an organ undergoing rapid growth and turnover of its epithelium.

A number of genes of interest were up-regulated in side-population trophoblasts relative to villous cytotrophoblasts or extravillous trophoblasts, including those involved in the first stages of trophectoderm differentiation in the blastocyst that are thought to be critical gatekeeper genes for trophoblast stem cell function in the mouse and those involved in maintaining an undifferentiated/pluripotent phenotype in other human stem cell populations (Table 2). The differences in expression of many of these genes were greater relative to extravillous trophoblasts than villous cytotrophoblasts. This not only reflects the fact that villous cytotrophoblasts are more closely related to sidepopulation trophoblasts but also is in agreement with previous data demonstrating the expression of genes thought to be restricted to murine trophoblast stem cells throughout the transit amplifying cytotrophoblast population in human placentae (Hemberger et al. 2010).

In the mouse placenta, Elf5, Cdx2, Eomes and Tcfap2 form a critical positive feedback loop defining murine trophoblast stem cell specification and reinforcement (Senner \& Hemberger 2010). Similarly, it has been proposed that in the human placenta ELF5 interacts with CDX2 and EOMES to establish a circuit of mutually interacting transcription factors, and an ELF5 and CDX2 positive population of putative trophoblast stem cells have been proposed to reside within the human placenta in the first trimester (Hemberger et al. 2010). However, it is evident both from molecular studies of bovine blastocysts (Berg et al. 2011) and anatomical studies highlighting the differences in implantation between mice and humans (James et al. 2012) that the regulatory networks governing trophectoderm specification and early trophoblast differentiation are likely to differ between murine models and those of other mammals. In our work, we observed a significant up-regulation of ELF5 in side-population cells relative to extravillous trophoblasts and in CDX2 expression relative to extravillous trophoblasts by homeobox array and microarray, although this could not be validated by real-time PCR. No significant difference in EOMES expression was observed, while TCFAP2 was not probed in the arrays. However, we did observe the up-regulation of 22 genes by side-population trophoblasts in comparison to both of the more mature trophoblast populations examined. Many of these 22 genes have previously been reported in stem cell niches in other tissues or play roles in embryonic development (Table 1). Furthermore, the majority of these genes have not previously been investigated in the placenta, and understanding how they may contribute to the regulation of trophoblast stem cell maintenance or differentiation in the human placenta is an exciting prospect for future work.

The stem cell niche plays an important role in regulating stem cell function within a tissue. Such niches 
can often be characterised by key extracellular matrix proteins that interact with stem cell adhesion molecules to maintain pluripotency or drive differentiation. Therefore, it was of interest that in this work almost one-third of the 22 genes identified as being uniquely up-regulated in side-population trophoblasts were either extracellular matrix proteins or adhesion molecules that may comprise such a niche (collagen $3 \alpha 1$, collagen $6 \alpha 3$, decorin, laminin $2 \alpha$, tenascin-C, thrombospondin-1, VCAM-1). Immunohistochemical localisation of some of these proteins in first trimester placentae indicated that markers of side-population trophoblasts are dispersed throughout the cytotrophoblast layer at the trophoblast/mesenchymal interface. Indeed, many epithelial stem cell populations are known to reside in close apposition to mesenchymal cells, and interactions between these cell types, including the ability of mesenchymal cells to control epithelial cell fate and the ability of epithelial cells to regulate mesenchymal cell organisation of tissue structure, are thought to play a key role in tissue morphogenesis (Birchmeier \& Birchmeier 1993, Blanpain et al. 2007).

It was also of interest to observe collagen $6 \alpha 3$ positive cells in the multilayered trophoblast in the tips of anchoring villi from which extravillous trophoblast outgrowths arise. Our previous work has co-localised the extracellular matrix protein tenascin-C, which was specifically up-regulated by side-population trophoblasts in this work, to these sites of extravillous trophoblast outgrowth initiation (James et al. 2007). Tenascin- $\mathrm{C}$ is found in many developing organs in the embryo, where it is most commonly expressed around budding or invaginating epithelia, but expression is largely lost in adult tissues where it is only evident in tissues bearing high tensile stress such as tendons and ligaments (Chiquet-Ehrismann et al. 2014). Tenascin-C is an important component of stem cell niches in a number of tissues, including the cornea and skin, due to its ability to regulate stem cell maintenance and renewal (Chiquet-Ehrismann et al. 2014). Functionally, tenascin-C can inhibit the activation of $\alpha 5 \beta 1$ integrin, one of the key integrins up-regulated during extravillous trophoblast differentiation (Huang et al. 2001, Midwood \& Schwarzbauer 2002) and, therefore, may play a particularly important role in maintaining a population of trophoblast stem cells in a pluripotent state at the site of extravillous trophoblast outgrowth initiation. Furthermore, the expression of markers of side-population trophoblasts in sporadic cells at both the sites of extravillous trophoblast outgrowth initiation and throughout the cytotrophoblast monolayer underlying the syncytiotrophoblast suggests that side-population trophoblasts may be capable of contributing to both of the major trophoblast lineages in the mature human placenta.

A handful of other researchers have previously attempted to isolate trophoblast progenitor populations from the placenta. Spitalieri et al. (2009) identified a population of cells within the cytotrophoblast layer of placental villi that express stem cell markers, but these cells gradually differentiate into fibroblasts and epithelial-like cells in culture rather than into more differentiated trophoblast lineages. More recently, Genbacev et al. (2011) isolated a population of continuously self-replicating TBPCs from the chorionic membrane of first trimester placentae. Our side-population trophoblasts show a very different gene expression profile compared to TBPC (Fig. 4), which up-regulate genes involved in neuronal development, stem cell pluripotency, integrin signalling and thrombin signalling (Genbacev et al. 2011). It is possible this may be a result of differences in the gestational age of the placentae from which the reference cytotrophoblast population was isolated in the two studies. Alternatively, in our study, trophoblasts were extracted using entirely different digestion methods and from placental villi rather than the chorionic membrane. We believe that these data indicate that we have isolated a novel population that differs significantly from TBPC isolated from the chorionic membrane described by Genbacev et al.

Due to the lack of available human trophoblast stem cell models, researchers have attempted to study the early human trophoblast differentiation pathways by employing a model in which $\mathrm{hESC}$ can be induced to differentiate into trophoblast-like cells when treated with BMP4 (Golos et al. 2013). This produces a heterogeneous population of trophoblast in which both multinucleated syncytium and HLA-G positive extravillous trophoblast-like cells can be observed (Golos et al. 2013). However, one of the issues surrounding this model is whether hESCs are truly being differentiated into trophoblast stem cell-like cells or whether they are forming a mesodermal cell lineage (Roberts et al. 2014). The catch-22 with this issue is that without an existing model of human trophoblast stem cells, we are unable to define what the molecular signature of true human trophoblast stem cell is. The isolation and molecular characterisation of side-population trophoblasts in this work may provide a step toward resolving this problem. However, to conclusively prove that side-population trophoblasts are true trophoblast stem cells and to be able to employ these stem cells as a useful model with which to understand trophoblast differentiation in early pregnancy, we must develop methods by which to differentiate them into the terminally differentiated trophoblast lineages: cytotrophoblast, syncytiotrophoblast and extravillous trophoblast. Confirmation that these side-population trophoblasts are true stem cells will require that they can be differentiated into transient trophoblast populations that appear at implantation, the primitive cytotrophoblast and primitive syncytium, which are functionally distinct from the mature cytotrophoblast and syncytiotrophoblast populations found during most of gestation.

In conclusion, we have isolated a novel sidepopulation of trophoblasts from first trimester human 
placental villi and demonstrated that these cells are a transcriptomically distinct population of trophoblasts that express some markers characteristic of progenitor/ stem cells. Future work to characterise the differentiation potential of these cells may provide a crucial link in our understanding of how placental organogenesis and trophoblast differentiation is regulated in early pregnancy and opens the door for future work to understand the factors regulating these processes and how they may be aberrant in pregnancy disorders.

\section{Declaration of interest}

The authors declare that there is no conflict of interest that could be perceived as prejudicing the impartiality of the research reported.

\section{Funding}

J L James was the recipient of an Auckland Medical Research Foundation Goodfellow Repatriation Fellowship. In addition, this work was funded through the award of project grants from the Auckland Medical Research Foundation and Maurice and Phyllis Paykel Trust.

\section{Acknowledgements}

We wish to thank the patients and staff at Auckland Medical Aid Centre for the donation of first trimester placental tissue required for this work. Our thanks also go to Mr Stephen Edgar for his flow cytometry expertise in sorting Hoechst sidepopulation cells, as well as the Centre for Genomics and Proteomics, University of Auckland and New Zealand Genomics Laboratory (NZGL) for their assistance in running the microarrays and bioinformatics expertise.

\section{References}

Aboagye-Mathiesen G, Laugesen J, Zdravkovic M \& Ebbesen P 1996 Isolation and characterization of human placental trophoblast subpopulations from first trimester chorionic villi. Clinical and Diagnostic Laboratory Immunology 3 14-22.

Aitken MA, Thomas T, Brennecke SP, Scott KF \& Rice GE 1996 Localization of type II phospholipase A2 messenger RNA and immunoactivity in human placenta and fetal membranes. Placenta 17 423-429. (doi:10.1016/S0143-4004(96)90024-7)

Andraweera PH, Dekker GA, Thompson SD, North RA, McCowan LM \& Roberts CT 2011 A functional variant in the thrombospondin-1 gene and the risk of small for gestational age infants. Journal of Thrombosis and Haemostasis 9 2221-2228. (doi:10.1111/j.1538-7836.2011. 04494.x)

Aschauer L, Gruber LN, Pfaller W, Limonciel A, Athersuch TJ, Cavill R, Khan A, Gstraunthaler G, Grillari J, Grillari R et al. 2013 Delineation of the key aspects in the regulation of epithelial monolayer formation. Molecular and Cellular Biology 33 2535-2550. (doi:10.1128/MCB. 01435-12)

Berg DK, Smith CS, Pearton DJ, Wells DN, Broadhurst R, Donnison M \& Pfeffer PL 2011 Trophectoderm lineage determination in cattle. Developmental Cell 20 244-255. (doi:10.1016/j.devcel.2011.01.003)

Birchmeier C \& Birchmeier W 1993 Molecular aspects of mesenchymalepithelial interactions. Annual Review of Cell Biology 9 511-540. (doi:10.1146/annurev.cb.09.110193.002455)
Blanpain C, Horsley V \& Fuchs E 2007 Epithelial stem cells: turning over new leaves. Cell 128 445-458. (doi:10.1016/j.cell.2007.01.014)

Chiquet-Ehrismann R, Orend G, Chiquet M, Tucker RP \& Midwood KS 2014 Tenascins in stem cell niches. Matrix Biology 37 112-123. (doi:10.1016/j.matbio.2014.01.007)

Connell LE \& Helfman DM 2006 Myosin light chain kinase plays a role in the regulation of epithelial cell survival. Journal of Cell Science $\mathbf{1 1 9}$ 2269-2281. (doi:10.1242/jcs.02926)

Cross JC, Simmons DG \& Watson ED 2003 Chorioallantoic morphogenesis and formation of the placental villous tree. Annals of the New York Academy of Sciences 995 84-93. (doi:10.1111/j.1749-6632.2003.tb03212.x)

Das P, Ezashi T, Schulz LC, Westfall SD, Livingston KA \& Roberts RM 2007 Effects of fgf2 and oxygen in the bmp4-driven differentiation of trophoblast from human embryonic stem cells. Stem Cell Research 1 61-74. (doi:10.1016/j.scr.2007.09.004)

Dodeur M, Malassine A, Bellet D, Mensier A \& Evain-Brion D 1990 Characterization and differentiation of human first trimester placenta trophoblastic cells in culture. Reproduction, Nutrition, Development 30 183-192. (doi:10.1051/rnd:19900204)

Fetting JL, Guay JA, Karolak MJ, lozzo RV, Adams DC, Maridas DE, Brown AC \& Oxburgh L 2014 FOXD1 promotes nephron progenitor differentiation by repressing decorin in the embryonic kidney. Development 141 17-27. (doi:10.1242/dev.089078)

Firulli BA, Howard MJ, McDaid JR, Mcllreavey L, Dionne KM, Centonze VE, Cserjesi P, Virshup DM \& Firulli AB 2003 PKA, PKC, and the protein phosphatase 2A influence HAND factor function: a mechanism for tissue-specific transcriptional regulation. Molecular Cell 12 1225-1237. (doi:10.1016/S1097-2765(03)00425-8)

Genander M \& Frisen J 2010 Ephrins and Eph receptors in stem cells and cancer. Current Opinion in Cell Biology 22 611-616. (doi:10.1016/ j.ceb.2010.08.005)

Genbacev O, Donne M, Kapidzic M, Gormley M, Lamb J, Gilmore J, Larocque N, Goldfien G, Zdravkovic T, McMaster MT et al. 2011 Establishment of human trophoblast progenitor cell lines from the chorion. Stem Cells 29 1427-1436. (doi:10.1002/stem.686)

Golos TG, Giakoumopoulos M \& Gerami-Naini B 2013 Review: Trophoblast differentiation from human embryonic stem cells. Placenta 34S S56-S61. (doi:10.1016/j.placenta.2012.11.019)

Hashimoto Y, Myojin R, Katoh N, Ohtsu M, Tashiro F, Onoda F \& Murakami Y 2009 The bHLH transcription factor Hand2 regulates the expression of nanog in ANS differentiation. Biochemical and Biophysical Research Communications 390 223-229. (doi:10.1016/j.bbrc.2009.09.090)

Hemberger M, Udayashankar R, Tesar P, Moore H \& Burton GJ 2010 ELF5enforced transcriptional networks define an epigenetically regulated trophoblast stem cell compartment in the human placenta. Human Molecular Genetics 19 2456-2467. (doi:10.1093/hmg/ddq128)

Huang W, Chiquet-Ehrismann R, Moyano JV, Garcia-Pardo A \& Orend G 2001 Interference of tenascin-C with syndecan-4 binding to fibronectin blocks cell adhesion and stimulates tumor cell proliferation. Cancer Research 61 8586-8594.

James J, Stone P \& Chamley L 2005 Cytotrophoblast differentiation in the first trimester of pregnancy: evidence for separate progenitors of extravillous trophoblasts and syncytiotrophoblast. Reproduction 130 95-103. (doi:10.1530/rep.1.00723)

James J, Stone P \& Chamley L 2007 The isolation and characterization of a population of extravillous trophoblast progenitors from first trimester human placenta. Human Reproduction 22 2111-2119. (doi:10.1093/ humrep/dem144)

James JL, Carter AM \& Chamley LW 2012 Human placentation from nidation to 5 weeks of gestation. Part I: What do we know about formative placental development following implantation? Placenta 33 327-334. (doi:10.1016/j.placenta.2012.01.020)

Kapp LD, Abrams EW, Marlow FL \& Mullins MC 2013 The integrator complex subunit 6 (Ints6) confines the dorsal organizer in vertebrate embryogenesis. PLoS Genetics 9 e1003822. (doi:10.1371/journal.pgen. 1003822)

Katoh M 2007 STAT3-induced WNT5A signaling loop in embryonic stem cells, adult normal tissues, chronic persistent inflammation, rheumatoid arthritis and cancer (Review). International Journal of Molecular Medicine 19 273-278. 
Lala N, Girish GV, Cloutier-Bosworth A \& Lala PK 2012 Mechanisms in decorin regulation of vascular endothelial growth factor-induced human trophoblast migration and acquisition of endothelial phenotype. Biology of Reproduction 87 59. (doi:10.1095/biolreprod.111.097881)

Liu X, Wu H, Byrne M, Krane S \& Jaenisch R 1997 Type III collagen is crucial for collagen I fibrillogenesis and for normal cardiovascular development. PNAS 94 1852-1856. (doi:10.1073/pnas.94.5.1852)

Liu ZK, Wang RC, Han BC, Yang Y \& Peng JP 2012 A novel role of IGFBP7 in mouse uterus: regulating uterine receptivity through Th1/Th2 lymphocyte balance and decidualization. PLOS ONE 7 e45224. (doi:10.1371/ journal.pone.0045224)

MacDonald BT \& He X 2012 Frizzled and LRP5/6 receptors for Wnt/ $\beta$-catenin signaling. Cold Spring Harbor Perspectives in Biology 4 1-23. (doi:10.1101/cshperspect.a007880)

Midwood KS \& Schwarzbauer JE 2002 Tenascin-C modulates matrix contraction via focal adhesion kinase- and Rho-mediated signaling pathways. Molecular Biology of the Cell 13 3601-3613. (doi:10.1091/ mbc.E02-05-0292)

Mullican SE, Zhang S, Konopleva M, Ruvolo V, Andreeff M, Milbrandt J \& Conneely OM 2007 Abrogation of nuclear receptors Nr4a3 and Nr4a1 leads to development of acute myeloid leukemia. Nature Medicine 13 730-735. (doi:10.1038/nm1579)

Murthi P, Rajaraman G, Brennecke SP \& Kalionis B 2011 The role of placental homeobox genes in human fetal growth restriction. Journal of Pregnancy 2011 548171. (doi:10.1155/2011/548171)

Oliver JR, Kushwah R \& Hu J 2012 Multiple roles of the epithelium-specific ETS transcription factor, ESE-1, in development and disease. Laboratory Investigation 92 320-330. (doi:10.1038/labinvest.2011.186)

Parr BA, Cornish VA, Cybulsky MI \& McMahon AP 2001 Wnt7b regulates placental development in mice. Developmental Biology 237 324-332. (doi:10.1006/dbio.2001.0373)

Redvers RP, Li A \& Kaur P 2006 Side population in adult murine epidermis exhibits phenotypic and functional characteristics of keratinocyte stem cells. PNAS 103 13168-13173. (doi:10.1073/pnas.0602579103)

Roberts RM, Loh KM, Amita M, Bernardo AS, Adachi K, Alexenko AP, Schust DJ, Schulz LC, Telugu BP, Ezashi T et al. 2014 Differentiation of trophoblast cells from human embryonic stem cells: to be or not to be? Reproduction 147 D1-D12. (doi:10.1530/REP-14-0080)

Samuel S, Walsh R, Webb J, Robins A, Potten C \& Mahida YR 2009 Characterization of putative stem cells in isolated human colonic crypt epithelial cells and their interactions with myofibroblasts. American Journal of Physiology. Cell Physiology 296 C296-C305. (doi:10.1152/ ajpcell.00383.2008)

Senner CE \& Hemberger M 2010 Regulation of early trophoblast differentiation - lessons from the mouse. Placenta 31 944-950. (doi:10.1016/j.placenta.2010.07.013)

Severino V, Alessio N, Farina A, Sandomenico A, Cipollaro M, Peluso G, Galderisi U \& Chambery A 2013 Insulin-like growth factor binding proteins 4 and 7 released by senescent cells promote premature senescence in mesenchymal stem cells. Cell Death \& Disease 4 e911. (doi:10.1038/cddis.2013.445)
Shaharuddin B, Harvey I, Ahmad S, Ali S \& Meeson A 2014 Characterisation of human limbal side population cells isolated using an optimised protocol from an immortalised epithelial cell line and primary limbal cultures. Stem Cell Reviews 10 240-250. (doi:10.1007/ s12015-013-9481-0)

Spitalieri P, Cortese G, Pietropolli A, Filareto A, Dolci S, Klinger FG, Giardina E, Di Cesare S, Bernardini L, Lauro D et al. 2009 Identification of multipotent cytotrophoblast cells from human first trimester chorionic villi. Cloning Stem Cells 11 535-556. (doi:10.1089/clo.2009.0046)

Sudheer S, Bhushan R, Fauler B, Lehrach H \& Adjaye J 2012 FGF inhibition directs BMP4-mediated differentiation of human embryonic stem cells to syncytiotrophoblast. Stem Cells and Development 21 2987-3000. (doi:10.1089/scd.2012.0099)

Suzuki N, Rohdewohld H, Neuman T, Gruss P \& Scholer HR 1990 Oct-6: a POU transcription factor expressed in embryonal stem cells and in the developing brain. EMBO Journal 9 3723-3732.

Takahashi K \& Yamanaka S 2006 Induction of pluripotent stem cells from mouse embryonic and adult fibroblast cultures by defined factors. Cell 126 663-676. (doi:10.1016/j.cell.2006.07.024)

Takao T, Asanoma K, Kato K, Fukushima K, Tsunematsu R, Hirakawa T, Matsumura S, Seki H, Takeda S \& Wake N 2011 Isolation and characterization of human trophoblast side-population (SP) cells in primary villous cytotrophoblasts and HTR-8/SVneo cell line. PLOS ONE 6 e21990. (doi:10.1371/journal.pone.0021990)

Tamm C, Bower N \& Anneren C 2011 Regulation of mouse embryonic stem cell self-renewal by a Yes-YAP-TEAD2 signaling pathway downstream of LIF. Journal of Cell Science 124 1136-1144. (doi:10.1242/jcs.075796)

Tanaka S, Kunath T, Hadjantonakis A, Nagy A \& Rossant J 1998 Promotion of trophoblast stem cell proliferation by FGF4. Science 282 2072-2075. (doi:10.1126/science.282.5396.2072)

Telugu BP, Adachi K, Schlitt JM, Ezashi T, Schust DJ, Roberts RM \& Schulz LC 2013 Comparison of extravillous trophoblast cells derived from human embryonic stem cells and from first trimester human placentas. Placenta 34 536-543. (doi:10.1016/j.placenta.2013.03.016)

Yagi R, Kohn MJ, Karavanova I, Kaneko KJ, Vullhorst D, DePamphilis ML \& Buonanno A 2007 Transcription factor TEAD4 specifies the trophectoderm lineage at the beginning of mammalian development. Development 134 3827-3836. (doi:10.1242/dev.010223)

Zhou S, Schuetz JD, Bunting KD, Colapietro AM, Sampath J, Morris JJ, Lagutina I, Grosveld GC, Osawa M, Nakauchi H et al. 2001 The ABC transporter Bcrp1/ABCG2 is expressed in a wide variety of stem cells and is a molecular determinant of the side-population phenotype. Nature Medicine 7 1028-1034. (doi:10.1038/nm0901-1028)

Received 10 December 2014

First decision 19 January 2015

Revised manuscript received 30 July 2015

Accepted 6 August 2015 